\title{
TJBF THE INFORMATION CONVEYED BY DEBT AND EQUITY ANNOUNCEMENTS IN AUSTRALIA
}

\author{
Oraluck Arsiraphongphisit \\ Deakin University, Australia
}

\begin{abstract}
This paper aims to report the findings associated with the effects of share prices around the disclosure dates of four different debt-and-equity fund-raising events over a 12-year period from 1991 to 2003 in Australia. By applying the well-known event study approach, along with the data-trimming procedures, a new idea is to remove all known confounding events and make corrections for thin-trading bias. The observed statistically significant price effects are consistent with theories: a positive price effect is observed for straight-debt and private placements whereas negative price effects occur when convertible debt and rights issues are announced. The results pertaining to the private placement effect is reported for the first time on this market. These findings are consistent with leverage, agency, and asymmetric information theories. It is believed that this study contributes new evidence on private placements and other events adding to existing literature surrounding the matter at hand.
\end{abstract}

Keywords: Equity private placement, Equity rights issue, Straight debt, Convertible debt, Cumulative abnormal returns JEL Classification: D92, G32

\section{Introduction}

A great deal of empirical analysis, particularly during the 1980s and 1990s, has been devoted to the observation of share price behavior surrounding the announcements of debt and equity financing, along with the way in which the issues are marketed. However, the majority of these studies have been limited to the U.S., as well as some European and Asian countries. The researchers had also examined data between 1965 and 1997; therefore, the findings have become obsolete since market structure has changed substantially over the last decade. To the author's knowledge, no study of this kind on straight debt, convertible debt, equity, and private placements exists in Australia. There are only two rights-issue studies to date. ${ }^{1}$

1 Only two rights studies have been done in Australia. This includes a published paper by Ball, Brown, and Finn (1977), as well as a PhD thesis by Dehnert (1993). 
Thus, the primary objective of this paper is to provide robust evidence on share price responses to these issues for a given period, ultimately adding new findings to the Australian Finance literature. In addition, this study seeks to examine and compare the effects of the four debt and equity capital events announced and issued over a simultaneous period, a phenomenon not seen elsewhere. To the author's knowledge, the analysis of the four financing types has not yet been reported. This study should also contribute fresh evidence to the literature while at the same time, resolving the debate over any ambiguous results on the rights issue price effects in the Australian market.

Corporations raise external capital by borrowing first and then offering different types of securities through various methods of capital financing. Aside from bank lending, equity financing has long been popular as a primary source of funds for firms. The methods used in raising equity externally were predominantly private placements and rights issues, accounting for 69 percent of the overall equity funding in $2006 .{ }^{2}$ Current equity funding trends would suggest that private placements and rights issues must have dominant price effects in the equity market. Although the debt market is less developed than the equity market, it has been growing significantly. In fact, private sector debt, including straight and convertible debts, has grown threefold in the past decade. It accounts for around 75 percent of the total debt securities outstanding (about A $\$ 810$ billion or US\$705 billion) in $2006 .^{3}$

Although secondary issues of both debt and equity are considered as new forms of financing for firms, they convey opposite information to the market about value. Based on theories such as the tax hypothesis (Modigliani and Miller, 1963), agency theory (Jensen and Meckling, 1976), and asymmetric information model (Myers and Majluf, 1984), the announcement of publicly traded straight debt (cheaper funds as long as debt is not beyond optimal) is associated with positive share price reactions. The sale of equity securities is generally associated with negative share price responses (overvalued shares, thus lower cost of funding). Being that convertible debt is a hybrid security, its debt and equity-related features have implications on changes in shareholders' wealth, thus affecting share price negatively. However, the literature further suggests that the market not only negotiates a firm's value through the types of securities issued, but also through methods of raising capital.

Equity private placements involve the sale of shares to institutions and/or high net worth investors. They generally convey favourable news through the so-called "white knights effect". The market in contrast reacts negatively to publicly traded equity securities like that of rights issues, which are pro-rata offerings of new shares to existing shareholders in proportion to their current share ownership of a firm in this market. Management is prone to resort to this type of funding when share prices are overvalued, thus a lower cost of capital, hence signalling an overvaluation to those purchasing rights. The effect is also due to the discount offered to the subscribers.

Evidence on share price reactions to different security types and their issuing methods are somewhat inconclusive. Studies on straight debt issues in U.S. markets have reported mixed results. For example, De Jong and Veld (2001) had reported

Source: Australian Stock Exchange.

ibid. 
positive market responses to straight debt, whereas Howton, Howton, and Perfect (1998) had detected negative price effects. However, market responses observed in European and Asian countries are consistently positive (e.g. in Europe by Brounen and Eichholtz (2001) and in Japan by Kang and Stulz (1996)). Extensive studies, particularly those done in the U.S., concentrated on share price reactions to rights issues and to a lesser extent, private placements. As found in studies conducted by Goh, Gombola, Lee and Liu (1999) and Cronqvist and Nilsson (2003), market participants generally perceive new information regarding private placements as a signal of good news, hence the allegory of the white knight coming to the rescue of troubled firms, suggesting a positive price reaction.

In contrast, announcements regarding rights issues are perceived as a signal of bad news, probably eliciting a negative share price reaction (e.g. in Miles and Perterson (2002) and Martin-Ugedo (2003)). However, unlike private placements where positive share price reactions are consistently observed over different countries, this is yet to be investigated in Australia. The literature on market reactions to rights issue announcements has yielded mixed results as well. ${ }^{4}$ For instance, while studies in Canada, New Zealand, the U.S., and the U.K. reveal negative share price reactions to rights issue announcements, those in European and Asian countries had reported mixed results.

The findings in this study are similar to that evidence found in the U.S. for all types of issues, except for straight debt. However, in terms of rights issues, the results are in contrast with studies in Japan, Korea, and Singapore. In this study, significant positive price effects to public sales of straight debt issues and equity private placements are revealed, whereas a significant negative effect is evident for publicly traded convertible debt securities and equity rights issues. These effects are consistent with theories, such as the tax hypothesis (under a classical tax regime), agency theory, and asymmetric information model. Also, the negative effects of announcements involving equity rights issues resolves the conflicting findings reported hitherto, perhaps due to the robust results from the absence of confounding effects in our research method, where the use of high frequency data and corrections for data errors were implemented.

Section 2 briefly reviews the relevant literature on theoretical issues, where as Section 3 discusses the data, methodology, and statistical procedures for data analysis. Lastly, Section 4 contains the results of the analyses, while a conclusion is provided in Section 5.

\section{Literature on Financing Effect}

A number of hypotheses have been advanced to explain share price behaviours resulting from an announcement of financing decisions. This section relates the theories that explain how markets react to different security types and their issuance methods. These theories will be articulated here in terms of their relevance to the study.

4 Mixed results are also evident in Australian studies. That is while Ball et al. (1977) report a positive price effect to rights issues, Dehnert (1993) detects a negative price effect. 
Tax hypothesis: The classical work of Modigliani and Miller (1958) perhaps best outlines the rudiments of this theory: in a perfect market, where there is no tax, financing choices are irrelevant to firm value. In a subsequent study, Modigliani and Miller (1963) relaxed some of the assumptions in their original model to include the effects of corporate tax in order to properly reflect the benefits of a tax shield. Given the tax-effect of borrowings, firm value can be increased through the use of debt. Miller (1977) argued that with the differences in personal tax rates across investors, debt should have no impact on firm value while DeAngelo and Masulis (1980) suggest that at some point the personal tax disadvantage of retaining debt is compensated by the corporate tax advantage of debt. Consequently, the net tax benefit is often positive, making debt still attractive. The results appear to support this interpretation.

Thus, the underlying theme in this hypothesis is that the issuance of debt should lead to positive share price responses, which in turn should increase firm value. New equity effectively reduces a shareholders' tax shield per share while new debt will generally increase their tax shield benefits. Moreover, the magnitude of these effects should be related to the amount of tax shield benefits obtained from debt financing (Brounen and Eichholtz, 2001). Therefore, low non-debt tax shield firms may face a larger announcement effect on share prices than high non-debt tax shield firms (DeAngelo and Masulis, 1980). Conversely, high non-debt tax shield firms may face a larger announcement effect than low non-debt tax-shield firms (Suchard, 1997).

Notwithstanding the above themes, the tax hypothesis generally has no implications for the methods of issuing securities (i.e. public or placements etc.), and thus it is unlikely to explain the effect that these methods may have on market expectations unless the specific conditions of the firms' capital structure are known. Also, the above arguments are mainly applied to countries operating within a classical tax system (i.e. no imputation, a fact in this market). Under dividend imputation tax regimes in which Australian firms operate, tax should not play an important role in debt or equity financing choices as shareholders are indifferent between debt and equity financing, given the role of imputation credits or single taxation at the corporate level, offsetting the tax on dividends. The tax hypothesis therefore provides no explanation under the imputation tax system.

Agency model: Jensen and Meckling (1976) are among the first to relate the economic theory of the firm as did others (Berle \& Means, (1932); Coase, (1937); \& Smith, (1776)) to modernize finance theory. In essence, they had argued that several parties have competing interests in the firm, including managers who act as agents for the principals, i.e., share- and debt-holders. They had further suggested that managers are expected to act in the best interest of shareholders. However, as utility maximizers, they will not always do so, which will invariably result in the incurrence of agency costs. They had observed that conflicts of interests between shareholders and managers are generally associated with the separation of ownership and control. They had predicted that the lower the managers' ownership, the higher the conflict of interest between shareholders and managers, and the higher the agency costs of equity. Therefore, the issue of equity, i.e. a decrease in managers' ownership, conveys unfavourable news, which results in a downward share price movement. 
However, the conflict of interest between shareholders and managers can be mitigated through debt financing, as debt reduces the amount of free cash flow available to a manager (Jensen, 1986; Stulz, 1990), thus increasing the monitoring of the managers by lenders. This is also known as the free cash flow hypothesis. Debt financing increases the managers' stake in a firm, binding the managers to perform and utilise assets more efficiently in order to meet debt obligations. Consequently, debt issuance should convey good news to the market, creating the potential for positive effects on share prices relative to equity issuance. This line of thought can also be viewed with Leland and Pyle's (1977) signalling model. A manager's willingness to increase his/her stake in a firm is positively related to share prices and in turn firm value. Thus, investors will see the raising of equity as a signal of overpriced shares.

Jensen and Meckling (1976) also identify another type of a conflict of interest between shareholders and debt-holders. This has been the subject of many studies, e.g. Galai and Masulis, (1976); Jensen and Meckling (1976); Myers (1977); and Smith and Warner (1979), all of which generally suggest that shareholders have incentives to maximise their own benefits, and not necessarily maximise firm value, at the expense of debt-holders (Masulis, 1988). This is the basis for a further theory, typically referred to as the wealth transfer hypothesis. Given that contractual restrictions of a firm's ability to issue debt (i.e. debt covenants) cannot completely prevent a manager's decisions to alter the capital structure of a firm, debt-holders risk and wealth can be still affected by changes in the capital structure (Fama and Miller, 1972).

The Option Pricing Theory also predicts this. Indeed, Galai and Masulis (1976) had demonstrated that wealth can be transferred from debt-holders to shareholders when there is an unexpected increase in the risk associated with the underlying assets of the firm's assets. As a result, the firm's value may decrease (Masulis, 1988). New debt can increase both the risk associated with asset degradation and risk of current debt-holders. Firstly, the higher the amount of debt, the greater the financial distress costs, and secondly, debt-holders bear the loss in the value of debt through the cost of failure or poor investment returns given the risks associated with underlying assets.

Note also that, while shareholders bear the loss in the value of equity, this loss can be offset by the gain of wealth transferred from debt-holders if investments are value-decreasing, and earn unlimited returns from profitable investments (Harris and Raviv, 1991). This implies that debt financing expropriates wealth from debtholders to shareholders. As a result, share market participants interpret debt issues as favourable news and react positively to debt announcements. Conversely, new equity financing reduces the risk of existing debt, and therefore transfers wealth from shareholders to debt-holders.

As a result, investors view the issue of new equity as unfavourable news and react negatively to equity announcements. However, it should also be noted that debt-holders are able to protect their interests from activities that decrease shareholder value (e.g., by debt covenants and discounts in securities), in which case, shareholders will bear the cost of investing in value-decreasing projects. This 
effect is commonly termed the asset substitution effect, which is also known as the agency cost of debt financing (Harris and Raviv, 1991).

The issue of new debt affects both the debt-holders' claim on the value of the firm's assets and the potential expropriation of wealth from debt-holders to shareholders. This implies that the specific characteristics of securities have implications for the wealth of stakeholders. Given this theme, Smith and Warner (1979) and Green (1984) had suggested the issue of a convertible debt (or warrants) as a compromised device to reduce conflicts of interest between debt-holders and shareholders. They argued that the conversion feature of convertibles makes it less attractive for shareholders to invest in non-profitable projects. This is because convertible debt-holders can convert their debt claims into shares, enjoying wealth increasing activities from the above expropriation process (Harris and Raviv, 1991).

Asymmetric information model: The information asymmetry theory suggests that managers are privy to inside information and are thus at a considerable informational advantage compared to outsiders regarding a firm's activities, value, and investment opportunities. Given this informational advantage, Ross (1977) suggested that managers have an incentive to convey information about their firm's prospect to the market through their financing activities. As managers' compensation packages and career paths are more often linked to a firm's level of performance, they are unlikely to commit to additional debt unless they are optimistic about future earnings and cash flows of the firm. Thus, issuing debt would be perceived by the market as a signal of quality and optimism regarding the future prospects of the firm. This would concomitantly lead to positive movements in share price.

Similar price behaviour is predicted by Leland and Pyle (1977). They had suggested that the level of share ownership retained by managers is a signal that managers are 'willing to invest in their own project'. Given that they have superior knowledge regarding future cash flows and prospects of the firm, the signal is positive (particularly given that they are potentially increasing their diversification risk by colloquially speaking 'retaining all their eggs in one basket'). Rational investors would thus perceive the level of managers' share ownership as a credible signal regarding a firm's quality (Masulis and Korwar, 1986). Negative share price responses are therefore predicted should managers issue new shares, which in turn reduce their portion of firm ownership.

Myers and Majluf (1984) had extended Ross's initial model to account for investment decisions. Their model is known as the adverse selection model. It is motivated by the asset value of a firm. They argue that if a firm requires funding to finance a profitable investment and management believes that the firms prevailing share price exceeds its intrinsic value, then the firm will issue equity (or to a lesser extent, convertible debt). As a result, a firm will use equity to finance the project only if the value of the firm increases and its existing shareholders benefit more than new shareholders. This follows the asymmetric information hypothesis that managers have superior information and act in the best interest of existing shareholders. Market participants perceive this as a wealth transfer mechanism and react negatively to equity financing, thus resulting in negative returns. Note also that the magnitude 
of the share price change is related to the extent to which a firm's share price is over/undervalued. The greater the overvaluation of a firm's share price, the more negative the market responds. Brennan and Kraus (1987) and Stein (1992) however suggest that such an adverse selection problem associated with equity financing can be mitigated through the use of convertible debt.

An alternative information asymmetry explanation is advanced by Miller and Rock (1985), namely implied cash flow change hypothesis. As in Ross (1977) and Leland and Pyle (1977), this hypothesis suggests that the quality of the firm is associated with a firm's performance. Their model assumes an accounting principle where sources and uses of funds must be matched. It predicts that a firm tends to raise new funds when its cash flow is weakening. Thus, an unexpected, new source of outside financing through either debt or equity alerts the market of some potentially dismal news, suggesting that the firm faces a higher risk of weak cash flow performance relative to the inability of the firm in achieving future obligations.

Unlike the previous signalling hypothesis, Miller and Rock (1985) had predicted a negative association between share price and either debt or equity offerings. In summary, asymmetric information theory generally predicts debt announcements are favourable and equity announcements are unfavourable. In addition, negative market responses can be reduced if there is little information asymmetry between market participants (Dierkens, (1991) and Korajczyk, Lucas and MacDonald, (1991)).

Rights issues offers no change in the existing fractional ownership (as hypothesised by Leland and Pyle (1977). There are also no apparent wealth transfers from existing to new shareholders, as assumed by Myers and Majluf (1984). Thus, only Ross's (1977) and Miller and Rock's (1985) hypotheses may be of relevance when explaining share price patterns surrounding rights issue announcements. Following these themes, since rights issues are an equity raising activity, we can expect a negative share price reaction once the news of rights offerings is available. Kabir and Roosenboom (2003) had suggested that although asymmetric information hypotheses can explain share price patterns around rights issues (i.e., if existing shareholders take up the rights issues and sell them to new investors), they do not apply if existing shareholders take up and hold the rights issues.

Hertzel and Smith (1993) had extended Myers and Majluf's (1984) study to include private placements. They posit that undervalued firms with profitable opportunities can mitigate the information asymmetry effect by using private placements as an alternative mechanism for equity financing. They explain that, when firms issue equity privately, a small group of private investors are able to evaluate value more closely than would public investors in the usual public issue process (Goh et al., 1999). Thus, if a firm does not have good future prospects or a stable flow of expected earnings, it cannot afford to carry out such an action, and accordingly, would not engage in such scrutiny. This is consistent with the findings in Szewczyk and Varma (1991). They base their analysis on the approach used by Myers and Majluf (1984), where private placements are considered as close substitutes for financial slack, suggesting that markets should react non-negatively to private financing. In this sense, the signalling hypothesis predicts that private 
placements of both equity and debt convey positive news to the market and should improve a firm's share price. This is also consistent with evidence found in Wruck (1989), Hertzel and Smith (1993), and Lee and Kocher (2001).

\section{Data and Methodology}

\subsection{Data}

Firm specific data: The initial sample consists of 137 straight debt issues, 80 convertible debt issues, 806 private placements, and 358 rights issues. They were announced and issued by companies listed on the Australian Stock Exchange (ASX) over the thirteen-year period from 1991, the timeframe in which the economy was relatively stable despite the Asian crisis that affected the Australian economy the least among those respective countries in the Asia-Pacific region. To be included in the initial sample, the announcements of interest must have a clear public disclosure date. Also, events that are announced concurrently with any potential confounding events are excluded from the study. These potential, confounding events that of which are announced within a five-day period before or after the event date are those that have the propensity to impact share prices. Additionally, announcements made by firms during the first year of listing were excluded. For each observation, the event date, daily share price, as well as any and all relevant market and financial data were collected. The primary source of data for event dates and market data were DatAnalysis, SIRCA, and Bloomberg databases. The financial data was collected from various sources, including Connect4, DatAnalysis, and Aspect Financial Analysis databases.

To ensure the reliability of results, this study further takes into account the problem of infrequent and thin trading in data the screening process because many securities (particularly small companies) are infrequently or thinly traded (Bartholody and Riding, 1994). This problem often prevails in the data collection process where there is a lack of share price data for securities with no trading (most studies do not reveal this information). This screening process yielded 60 straight debt, 43 convertible debt, 377 private placement, and 158 rights observations. Summary statistics for all security offerings used in this study are presented in Table 1.

Table 1: Descriptive Statistics

Table 1 reports the descriptive statistics for 60 straight debt, 43 convertible debt, 377 private placement, and 158 rights observations.

\begin{tabular}{lrrrrr}
\hline \multicolumn{1}{c}{ Mean } & Median & Std. Deviation & Minimum & \multicolumn{1}{c}{ Maximum } \\
\hline \multicolumn{2}{l}{ Panel A: Straight debt issues } & & & & \\
\hline Total assets (\$) & $10,124,910,295$ & $2,334,736,000$ & $30,162,132,835$ & $3,102,000$ & $251,714,000,000$ \\
Total liabilities (\$) & $8,893,626,045$ & $1,918,707,000$ & $28,351,428,868$ & 56,000 & $235,950,000,000$ \\
$\begin{array}{l}\text { Interest bearing } \\
\text { debt (\$) }\end{array}$ & $7,677,315,987$ & $1,063,745,000$ & $23,096,331,375$ & 0 & $188,008,000,000$ \\
Total equity (\$) & $1,344,513,469$ & $821,210,000$ & $2,275,036,775$ & $12,242,868$ & $15,761,000,000$ \\
\hline
\end{tabular}


(continued)

\begin{tabular}{|c|c|c|c|c|c|}
\hline Outstanding shares & $394,074,218$ & $358,103,552$ & $304,094,768$ & $21,000,000$ & $1,447,649,492$ \\
\hline $\begin{array}{l}\text { Tax shield from } \\
\text { issues }(\$)\end{array}$ & $90,298,551$ & $61,649,114$ & $95,422,265$ & $2,700,000$ & $720,000,000$ \\
\hline $\begin{array}{l}\text { Market } \\
\text { capitalisation (\$) }\end{array}$ & $1,919,555,344$ & $940,678,285$ & $3,622,466,176$ & $13,440,000$ & $29,459,667,162$ \\
\hline Issue sizes $(\$)$ & $257,198,883$ & $176,429,076$ & $266,072,544$ & $7,500,000$ & $2,000,000,000$ \\
\hline $\begin{array}{l}\text { Issue sizes/Market } \\
\text { cap. }\end{array}$ & $13.40 \%$ & $18.76 \%$ & $7.35 \%$ & $55.80 \%$ & $6.79 \%$ \\
\hline \multicolumn{6}{|c|}{ Panel B: Convertible debt issues } \\
\hline Total assets $(\$)$ & $1,054,359,992$ & $175,248,636$ & $1,840,866,059$ & $2,716,752$ & $4,955,700,000$ \\
\hline Total liabilities $(\$)$ & $702,210,163$ & $40,314,000$ & $1,202,725,141$ & 601,516 & $3,098,700,000$ \\
\hline $\begin{array}{l}\text { Interest bearing } \\
\operatorname{debt}(\$)\end{array}$ & $434,569,767$ & $11,790,000$ & $720,040,856$ & 0 & $1,645,200,000$ \\
\hline Total equity (\$) & $352,149,829$ & $121,365,000$ & $670,190,819$ & $2,115,236$ & $1,857,000,000$ \\
\hline Outstanding shares & $327,885,066$ & $301,530,000$ & $273,906,965$ & $32,968,005$ & $699,922,121$ \\
\hline $\begin{array}{l}\text { Tax shield from } \\
\text { issues (\$) }\end{array}$ & $52,147,769$ & $13,680,000$ & $59,635,283$ & 340,000 & $133,307,195$ \\
\hline $\begin{array}{l}\text { Market } \\
\text { capitalisation }(\$)\end{array}$ & $868,892,404$ & $321,964,176$ & $1,318,521,882$ & $3,626,481$ & $3,645,225,166$ \\
\hline Issue sizes (\$) & $148,117,452$ & $38,000,000$ & $170,578,584$ & $1,000,000$ & $392,079,984$ \\
\hline $\begin{array}{l}\text { Issue sizes/Market } \\
\text { cap. }\end{array}$ & $17.05 \%$ & $11.80 \%$ & $12.94 \%$ & $27.57 \%$ & $10.76 \%$ \\
\hline \multicolumn{6}{|c|}{ Panel C: Private placement issues } \\
\hline Total assets $(\$)$ & $32,802,403$ & $11,180,762$ & $64,421,760$ & 572,175 & $342,515,578$ \\
\hline Total liabilities $(\$)$ & $16,165,084$ & 873,561 & $43,964,997$ & 10,476 & $235,366,118$ \\
\hline $\begin{array}{l}\text { Interest bearing } \\
\text { debt }(\$)\end{array}$ & $6,686,697$ & 21,028 & $13,959,072$ & 0 & $57,845,602$ \\
\hline Total equity (\$) & $16,637,320$ & $9,058,056$ & $22,375,731$ & 561,699 & $107,149,459$ \\
\hline Outstanding shares & $107,691,381$ & $96,856,178$ & $85,691,044$ & $12,417,764$ & $419,206,323$ \\
\hline $\begin{array}{l}\text { Market } \\
\text { capitalisation (\$) }\end{array}$ & $44,866,576$ & $25,921,896$ & $63,717,898$ & $1,494,935$ & $324,512,090$ \\
\hline Issue sizes (\$) & $5,852,752$ & $3,464,800$ & $8,164,678$ & 104,125 & $40,000,000$ \\
\hline $\begin{array}{l}\text { Issue sizes/Market } \\
\text { cap. }\end{array}$ & $13.04 \%$ & $13.37 \%$ & $12.81 \%$ & $6.97 \%$ & $12.33 \%$ \\
\hline \multicolumn{6}{|c|}{ Panel D: Rights issues } \\
\hline Total assets $(\$)$ & $150,252,117$ & $10,299,000$ & $283,557,471$ & $4,024,867$ & $853,240,000$ \\
\hline Total liabilities $(\$)$ & $59,215,302$ & $6,094,513$ & $129,956,012$ & 19,000 & $399,196,000$ \\
\hline $\begin{array}{l}\text { Interest bearing } \\
\text { debt }(\$)\end{array}$ & $34,289,941$ & $4,200,000$ & $74,100,821$ & 0 & $228,432,000$ \\
\hline Total equity (\$) & $91,036,815$ & $10,124,000$ & $165,623,888$ & $3,910,232$ & $454,044,000$ \\
\hline Outstanding shares & $176,948,617$ & $64,167,271$ & $210,767,173$ & $21,291,190$ & $604,360,999$ \\
\hline $\begin{array}{l}\text { Market } \\
\text { capitalisation }(\$)\end{array}$ & $76,681,078$ & $13,227,512$ & $130,620,247$ & $3,755,870$ & $355,281,744$ \\
\hline Issue sizes (\$) & $14,915,486$ & $2,055,707$ & $22,376,723$ & 850,956 & $56,146,969$ \\
\hline $\begin{array}{l}\text { Issue sizes/Market } \\
\text { cap. }\end{array}$ & $19.45 \%$ & $15.54 \%$ & $17.13 \%$ & $22.66 \%$ & $15.80 \%$ \\
\hline
\end{tabular}


The first four rows of each panel show the summary measures in dollar size the total assets, total liabilities, interest bearing debt, and total equity of firms issuing securities in question. Firms issuing straight debt have the highest median amount of all interested characteristics. The dollar size of the offerings is presented in the second last row of each panel. The median amount ranges are from \$2.06 million for rights issues to $\$ 176.5$ for straight debt offerings. The median market capitalisation of firms issuing straight debt is also much larger than that of firms issuing other types of securities. However, based on comparable dollar amounts measured relative to the market capitalisation of the issuing firms, the percentage of the median amount issued relative to the market capitalisation is $18.76 \%, 11.8 \%, 13.37 \%$, and $15.54 \%$ for straight debt, convertible debt, private placement, and rights issues, respectively. These figures imply that firms rely more heavily on straight debt than other types of issues. Nevertheless, should they need equity financing, they will prefer rights issues to private placements. Perhaps this is so being that private placements are subject to a limited number of shares or amount that can be funded.

The median issue size from straight debt issues is about $\$ 176.5$ million with a minimum of $\$ 7.5$ million and a maximum of $\$ 200$ million. This represents $18.76 \%$ of the firm's market capitalisation before the straight debt issues. This amount is larger than that of the U.S. market, in which the percentage of straight debt issues represents $13.6 \%$ of the firm's market capitalisation over the period over 1977-1984 (Mikkelson and Partch, 1986). As hybrid securities can be structured to mitigate informational effects, firms in Australia appear to undertake some convertible debts over the past decade. The median issue size from the convertible debt issues is about $\$ 38$ million, representing $11.8 \%$ of the firm's market capitalisation. This percentage is smaller than the U.S. market's figure, amounting to $13.2 \%$ over the period of 19721982 (Mikkelson and Partch, 1986) and 20\% over the period of 1978-1992 (Lewis, Rogalski, and Seward, 2003). Unlike debt financing, the percentage of the issue size to the market capitalisation of firms issuing private placement in Australia is higher than in the U.S. Although the median issue size from the private placement issues is small (about $\$ 3.5$ million), it represents $13.37 \%$ of the firm's market capitalisation before the issues. This figure is slightly higher than that of the U.S. (11.75\%) over the period of 1980-1987 (Hertzel and Smith, 1993).

Lastly, Australian firms also raised capital through rights issues, representing $15.54 \%$ of the firm's market capitalisation with the median amount of $\$ 2$ million and maximum mount of $\$ 56$ million. However, when comparing descriptive figures between countries/studies, one should be aware of the analysis periods, which in most cases are different.

Share prices and market index: Closing share prices were used and the All Ordinaries Accumulation Index (XAO_A) was used as a proxy for the market index. For each event, the event date is defined as time 0. Daily share prices and XAO_A are collected for the period surrounding the respective events. These data were collected from the DataStream and SIRCA databases. Similar to earlier studies, the data used in this study are adjusted for stock dividends and changes in capital, such as stock splits. 


\section{Methodology}

The analysis of share price reactions was conducted within a standard event study framework as described in Brown \& Warner (1980; 1985). In this study, the market adjusted returns method is employed for abnormal return computations for both private placements and rights issues. The event periods are various in order to ensure that the period is long enough to capture the significant effect of the event, yet short enough to exclude confounding effects (McWilliams \& Siegel, 1997).

Market adjusted model: The market adjusted return model describes ex-post abnormal returns as follows:

$A R_{i, t}=R_{i, t}-R_{m, t}$

Where :

$t \quad:$ days measured relative to the event date

$A R_{i, t}:$ excess or abnormal returns

$R_{i, t} \quad: \quad$ the rate of return on security $i$ in period $t$

$R_{m, t}:$ the rate of return on market index in period $t$

Table 2 on the following page represents the predicted signs of abnormal returns following each type of financing event based on theories discussed in theoretical section. In general, a positive share price reaction to debt securities is expected, whereas a negative share price effect is expected for equity securities. However, when placing the securities privately, the market appears to act positively to both debt and equity issues.

This model estimates expected or predicted returns as follows:

$R_{i, t}=R_{m, t}$

Consistent with Strong (1992), for each announcement, the return on each day being studied is computed as follows:

$R_{i, t}=\ln \left[\frac{P_{i, t}+D_{i, t}}{P_{i, t-1}}\right]$

Where

$P_{i, t} \quad: \quad$ the price of security $i$ in period $\mathrm{t}$, adjusted for capital changes

$D_{i . t} \quad$ : the dividend received from security $i$ in period $t$.

The abnormal returns across firms on the same event date are cumulated across firms to obtain the average abnormal return over time. Then, the Cumulative Average Residuals (CARs, or the sum of average abnormal returns during time $t$ within the event window) are calculated based on Fama, Fisher, Jensen and Roll's (1969) procedure. The following arithmetic method is applied: 
Table 2: Predicted Signs of Abnormal Returns Following Four Financing Events

\begin{tabular}{|c|c|c|c|c|c|}
\hline & \multirow{2}{*}{\multicolumn{2}{|c|}{$\frac{\text { Debt security }}{\text { Public offerings }}$}} & \multirow{2}{*}{\multicolumn{2}{|c|}{$\begin{array}{l}\text { Equity security } \\
\text { Public offerings }\end{array}$}} & \multirow{3}{*}{$\begin{array}{c}\text { Private } \\
\text { Placements }\end{array}$} \\
\hline & & & & & \\
\hline & $\begin{array}{c}\text { Straight } \\
\text { debt }\end{array}$ & $\begin{array}{c}\text { Convertible } \\
\text { debt }\end{array}$ & Shares & $\begin{array}{l}\text { Rights } \\
\text { of shares }\end{array}$ & \\
\hline Tax Hypothesis ${ }^{\#}$ & + & $+/-\wedge$ & - & - & \\
\hline \multicolumn{6}{|l|}{ Agency Theory } \\
\hline $\begin{array}{c}\text { - Free cash flow } \\
\text { hypothesis }\end{array}$ & + & + & - & - & + \\
\hline $\begin{array}{c}\text { - Wealth transfer } \\
\text { hypothesis }\end{array}$ & + & + & - & - & \\
\hline \multicolumn{6}{|l|}{ Signalling Hypothesis } \\
\hline $\begin{array}{l}\text { - Firm quality hypothesis } \\
\text { (Ross, 1977and Leland } \\
\text { \& Pyle, 1977) }\end{array}$ & + & + & - & - & \\
\hline $\begin{array}{l}\text { - Adverse selection } \\
\text { model } \\
\text { (Myers \& Majluf, } \\
\text { 1984) }\end{array}$ & + & + & - & - & + \\
\hline $\begin{array}{l}\text { - Implied cash flow } \\
\text { change } \\
\text { hypothesis (Miller \& } \\
\text { Rock, 1985) }\end{array}$ & - & - & - & - & \\
\hline
\end{tabular}

\# Under the classical tax regime, the tax hypothesis generally predicts a positive (negative) share price reaction to debt (equity) announcements. The imputation tax system aims to eliminate the double taxation inherent in the classical system and to remove any tax advantages of debt. Therefore, while firms under the classical system are biased toward debt, those under the imputation system are biased toward equity. This subsequently gives rise to a neutral effect between debt and equity. The table however, presents the effects under the classical tax system.

$\wedge$ A convertible debt can be structured as equity-liked or debt-liked security. If it is designed to primarily possess straight debt features, a positive share price reaction is expected.

However, a negative effect is expected if the issue predominantly possesses equity features.

$A A R_{t}=\frac{1}{N} \sum_{i=1}^{N} A R_{i, t}$ 


$$
C A R_{(j, k)}=\sum_{t=j}^{k} A A R_{t}
$$

Where

$A A R_{t} \quad: \quad$ the average abnormal returns for $N$ securities in period $t$,

$N \quad:$ the number of securities in the portfolio AND

$C A R_{(j, k)} \quad: \quad$ cumulative abnormal returns between time $j$ and $k$.

The statistical procedure for data analysis in this study employs the conventional $t$-test statistics. The null hypothesis is tested using test statistics discussed in Brown and Warner (1985), Corrado (1989), and Corrado and Zivney (1992). This test depends upon the cross-sectional independence of the securities' abnormal returns for the correct specifications (Corrado, 1989). According to Brown and Warner (1985), if the assumption that the cross-sectional independence is valid, the $t$-statistics used in this study is better than the one that equals to $A A R / \sigma_{A A R}$. The $t$-statistics of the average abnormal return for any event day $t$ used in this study is:

$$
\begin{aligned}
t \text { statistics of AAR } & =\frac{A A R_{t}}{S E E_{A A R}} \\
& =\frac{\sigma_{A A R}}{\sqrt{N}} \\
& =\sqrt{\frac{\left(\sum_{t=m}^{t=n}\left(A A R_{t}-\overline{A A R_{\mathrm{int}}}\right)^{2}\right)}{(P-1)}} \\
& =\frac{1}{N} \sum_{t=m}^{t=n} A A R_{t}
\end{aligned}
$$

Where

$t$ statistics

of AAR : $\quad t$-test of mean standardized abnormal returns,

$S E E_{A A R} \quad: \quad$ the standard error of estimates of the average abnormal returns of observations within the estimation period,

$\sigma_{A A R} \quad:$ the standard deviation of the average abnormal return,

${\frac{A A R}{A A R_{\text {int }}}}_{\text {: }}$ the average of the average abnormal returns during the interested period,

$m \quad: \quad$ the beginning of the interested period,

$n \quad: \quad$ the end of the interested period, and

$P \quad$ : number of days in the interested period or $|m-n|+1$.

The $t$-statistics of cumulative abnormal return for any specific interval is: 
$\begin{aligned} t \text { statistics of CAR } & =\frac{C A R_{(k, l)}}{S E E_{C A R}} \\ & =\sqrt{T} \sigma_{A A R}\end{aligned}$

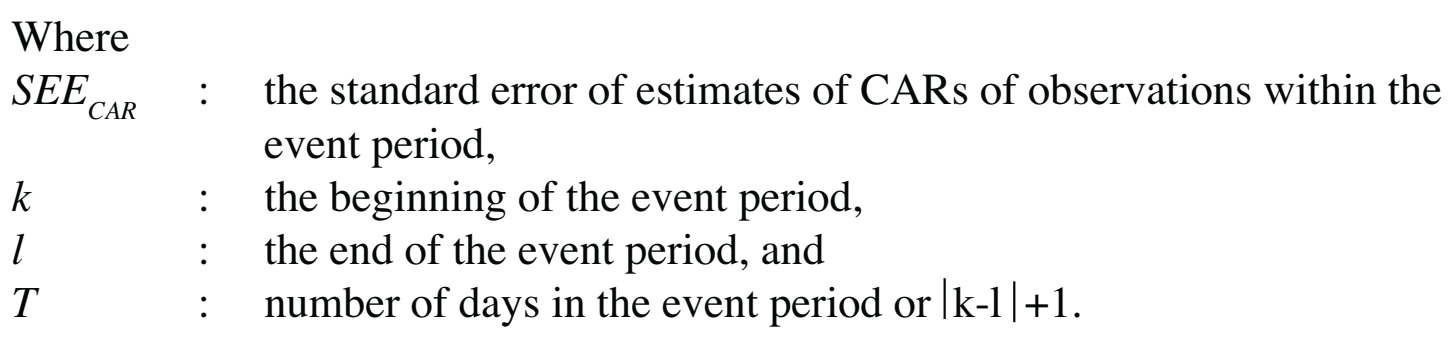

\section{Results}

\subsection{Share Price Reactions to Public Straight Debt Announcements}

AARs and CARs for the sample of straight debt are presented in Table 3.

The results show that straight debt issues have a slight effect on share prices. In fact, the AAR for the day prior to the event date (day -1), the event date (day 0), and the day after the event date (day -1) are 0.29 percent, 0.22 percent, and 0.09 percent, respectively. They are positive but are not statistically significant. In addition, the CARs for the whole test period $(-10,+10)$ and the pre-event period $(-10,-1)$ are positive at 1.33 and 0.71 percent, respectively, and statistically significant at the 0.05 level. The CAR for the on-event period $(-1,+1)$ is also positive at 0.60 percent, but it is more statistically significant at the 0.01 level. Although the CAR for the post-event period $(+2,+10)$ is positive, it is not statistically significant. These results are consistent with a market that is efficient in the semi-strong form in which share prices adjust rapidly to new information.

It is also noted that the positive, average, three-day market responses to straight debt announcements observed in this study are consistent with those results obtained from studies done in Spain by Arrondo \& Gomez-Anson (2003) and in the U.S. by Howe and Shilling (1988). The majority of U.S. studies report negative results. Through the observance of industrial firms, Arrondo and Gomez-Anson (2003) revealed a positive return of 0.68 percent, which is statistically significant at the 0.01 level. Similarly, while observing real estate investment trusts (REITs), Howe and Shilling (1988), had reported a significantly positive return of 1.94 percent. Positive results are also found in other studies; however, they are insignificant (e.g. in the U.S. by Johnson (1995) and Lewis et al. (1999), in Japan by Kang and Stulz (1996), and in European countries by Brounen and Eichholtz (2001) ${ }^{5}$. The positive share price reactions resulting from straight debt issue announcements in this study are consistent with the agency hypothesis, including the free cash flow and wealth transfer hypotheses, and the asymmetric information model, as discussed in the previous sections. However, the results are inconsistent with the tax hypothesis in

5 Those six European countries include France, Netherlands, Norway, Portugal, Spain, and the U.K. 
Table 3: Daily Average Abnormal Returns and Cumulative Abnormal Returns Surrounding Public Straight Debt Announcements

\begin{tabular}{cccccc}
\hline \multicolumn{7}{c}{ AAR $(\%)$} & CAR $(\%)$ & Std Dev. & SEE & t-statistics \\
\hline Panel A: AAR and CAR & & & & \\
-10 & 0.2246 & 0.2246 & 0.0151 & 0.0020 & 1.1449 \\
-9 & 0.0257 & 0.2503 & 0.0163 & 0.0021 & 0.1201 \\
-8 & -0.0353 & 0.2150 & 0.0127 & 0.0016 & -0.2146 \\
-7 & -0.0050 & 0.2100 & 0.0149 & 0.0020 & -0.0256 \\
-6 & 0.1494 & 0.3594 & 0.0175 & 0.0023 & 0.6561 \\
-5 & 0.0086 & 0.3680 & 0.0119 & 0.0016 & 0.0549 \\
-4 & -0.0492 & 0.3188 & 0.0210 & 0.0027 & -0.1801 \\
-3 & 0.0421 & 0.3609 & 0.0171 & 0.0022 & 0.1887 \\
-2 & 0.0595 & 0.4204 & 0.0162 & 0.0021 & 0.2852 \\
-1 & 0.2931 & 0.7135 & 0.0184 & 0.0025 & 1.1923 \\
0 & 0.2220 & 0.9356 & 0.0184 & 0.0025 & 0.9041 \\
1 & 0.0866 & 1.0222 & 0.0145 & 0.0019 & 0.4498 \\
2 & -0.1049 & 0.9172 & 0.0118 & 0.0015 & -0.6909 \\
3 & -0.0722 & 0.8450 & 0.0158 & 0.0020 & -0.3541 \\
4 & 0.0798 & 0.9249 & 0.0152 & 0.0020 & 0.4065 \\
5 & 0.0105 & 0.9354 & 0.0121 & 0.0016 & 0.0663 \\
6 & 0.0348 & 0.9701 & 0.0131 & 0.0017 & 0.2037 \\
7 & -0.1263 & 0.8439 & 0.0090 & 0.0012 & -1.0689 \\
8 & 0.1291 & 0.9730 & 0.0130 & 0.0017 & 0.7674 \\
10 & -0.0973 & 0.8756 & 0.0129 & 0.0017 & -0.5848 \\
\hline & 0.4628 & 1.3385 & 0.0132 & 0.0018 & $2.6182 * *$ \\
\hline
\end{tabular}

Panel B: Cumulative windows

\begin{tabular}{ccccc}
$-10,+10$ & 1.3385 & 0.1449 & 0.6642 & $2.0151^{* *}$ \\
$-10,-1$ & 0.7135 & 0.1143 & 0.3614 & $1.9745^{* *}$ \\
$-1,+1$ & 0.6018 & 0.1049 & 0.1817 & $3.3121^{* * *}$ \\
$+2,+10$ & 0.3163 & 0.1834 & 0.5502 & 0.5748 \\
\hline
\end{tabular}

$* * *$ Indicates statistical significance at the 0.01 level.

** Indicates statistical significance at the 0.05 level.

* Indicates statistical significance at the 0.10 level.

$$
\text { a } A A R_{t}=\frac{1}{N} \sum_{i=1}^{N} A R_{i, t} \quad \mathrm{~b} C A R_{(j, k)}=\sum_{t=j}^{k} A A R_{t}
$$


the imputation context where the market should be indifferent between issuing debt or equity securities.

\subsection{Share Price Reactions to Public Convertible Debt Announcements}

AARs and CARs for the sample of convertible debt announcements are presented below in Table 4. Although the results show that convertible debt issues have a significant negative effect on share prices during the event period, the issues did not significantly affect share price movements on particular trading days during the observed period. While the AAR for day -1 is positive, the AARs for day 0 and day -1 are negative. In addition, all of these AARs are not statistically significant. Both CARs for the entire test period, i.e. days -10 to +10 , and the pre-event period, i.e. days -10 to -1 , are not statistically significant. While the former window demonstrates a negative effect to the convertible debt announcements, the latter window shows a positive effect.

However, the analysis of a small event window proves the phenomenon to be a significant event, as it is apparent from the table that CARs for both of the on-event periods, i.e. days -1 to 0 and -1 to +1 , are negative at -0.61 percent and -1.19 percent, and statistically significant at the 0.05 and 0.01 level, respectively. The insignificance of CARs during the post-event period, i.e. days +2 and +10 , are consistent with market efficiency in which share prices adjust rapidly to new information and no abnormal returns should be earned as share prices already fully reflect all available information.

This study reports a negative, average, two-day market reaction to convertible debt announcements. The abnormal return and the significant $t$-test findings obtained from this study are consistent with results obtained in many U.S. studies, like that of Lewis et al. (1997) \& Burlacu (2000). The share price responses observed in these studies were all statistically significant at the 0.01 level.

While most hypotheses such as the tax hypothesis (under a classical tax regime), free cash flow hypothesis, firm quality hypothesis (Leland and Pyle, 1977; Ross, 1977), and adverse selection model (Myers and Majluf, 1984), predict that leverage-increasing events convey favourable news to the market and leveragedecreasing events convey unfavourable news, the results of this study contrast with this theoretical prediction. The significant negative results obtained from this study may be a result of the expected conversion time of the issue. The market will price the convertible issue based upon the expected conversion period. If the time to expected conversion is short, the market will react to convertible issues in a similar fashion to when it responds to equity issues (Davidson, Glascock, and Schwartz, 1995). In other words, the market may perceive dilution effects that result from the conversion of the issue into equity of a firm.

Such uncertainty of wealth per share is therefore immediately impounded to the price at the time when the convertible security is issued. Another plausible explanation is in regards to the characteristics of convertible issues. The dichotomised characteristics (debt and equity claims) of convertible issues make it difficult, or if not impossible, for investors to precisely estimate an issuing firm's financial leverage and/or analyse the real purpose of convertible debt. 
Table 4: Daily Average Abnormal Returns and Cumulative Abnormal Returns Surrounding Convertible Debt

\begin{tabular}{cccccc}
\hline \multicolumn{7}{c}{ AAR $(\%)$} & CAR $(\%)$ & Std Dev. & SEE & t-statistics \\
\hline Panel A: AAR and CAR & & & & \\
-10 & 0.5019 & 0.5019 & 0.0354 & 0.0054 & 0.9733 \\
-9 & -0.5243 & -0.0223 & 0.0338 & 0.0052 & -0.8909 \\
-8 & -0.0344 & -0.0568 & 0.0386 & 0.0059 & -0.0589 \\
-7 & 1.1167 & 1.0599 & 0.0374 & 0.0058 & 1.6350 \\
-6 & -0.7929 & 0.2670 & 0.0432 & 0.0068 & -0.7835 \\
-5 & 0.4906 & 0.7576 & 0.0664 & 0.0101 & 0.9697 \\
-4 & 0.2525 & 1.0101 & 0.0328 & 0.0051 & 0.3751 \\
-3 & -0.2939 & 0.7162 & 0.0441 & 0.0067 & -0.4163 \\
-2 & 0.0774 & 0.7936 & 0.0463 & 0.0071 & 0.1017 \\
-1 & -0.4508 & 0.3428 & 0.0499 & 0.0076 & -1.1420 \\
0 & -0.1589 & 0.1839 & 0.0259 & 0.0039 & -0.2534 \\
1 & -0.5797 & -0.3959 & 0.0411 & 0.0063 & -0.6185 \\
2 & -2.0247 & -2.4205 & 0.0615 & 0.0094 & -1.4268 \\
3 & 0.6060 & -1.8145 & 0.0931 & 0.0142 & 1.0992 \\
4 & 0.1594 & -1.6551 & 0.0357 & 0.0055 & 0.2380 \\
5 & -0.2020 & -1.8571 & 0.0439 & 0.0067 & -0.3570 \\
6 & 0.0168 & -1.8403 & 0.0371 & 0.0057 & 0.0261 \\
7 & -0.0674 & -1.9077 & 0.0423 & 0.0064 & -0.1238 \\
8 & 0.1314 & -1.7763 & 0.0357 & 0.0054 & 0.1517 \\
9 & 0.3323 & -1.4440 & 0.0568 & 0.0087 & 0.5084 \\
10 & -0.1322 & -1.5762 & 0.0429 & 0.0065 & -0.2128 \\
\hline
\end{tabular}

\section{Panel B: Cumulative windows}

\begin{tabular}{ccccc}
$-10,+10$ & -1.5762 & 0.6297 & 2.8855 & -0.5463 \\
$-10,-1$ & 0.3428 & 0.5766 & 1.8233 & 0.1880 \\
$-1,+1$ & -1.1895 & 0.2156 & 0.3734 & $-3.1851^{* * *}$ \\
$+2,+10$ & -1.1804 & 0.7523 & 2.2570 & -0.5230 \\
\hline
\end{tabular}

*** Indicates statistical significance at the 0.01 level.

** Indicates statistical significance at the 0.05 level.

*Indicates statistical significance at the 0.10 level.

$$
\mathrm{a} \quad A A R_{t}=\frac{1}{N} \sum_{i=1}^{N} A R_{i, t} \quad \mathrm{~b} \quad C A R_{(j, k)}=\sum_{t=j}^{k} A A R_{t}
$$


Consequently, this may distort the positive effect of the first claim component of the convertible issue. The findings of this study are however consistent with the model developed by Miller and Rock (1985), which they had predicted a negative correlation associated with either debt or equity offerings. Miller and Rock's (1985) model relied on the decision to obtain new financing rather than types of financing. They had suggested that the decision to raise new funds reveals the weakening cash flow of an issuing firm. Thus, they had predicted the same share price response for both debt and equity announcements.

\subsection{Share Price Reactions to Private Placement Announcements}

AARs and CARs for the sample of private placements are presented on the following page in Table 5.

The results show that the AARs for the day prior to the event date (day -1), the event date itself (day 0), and the day after the event date (day -1) are positively and statistically significant at the 0.01 level, except for day 0 , which is statistically significant at the 0.05 level. In addition, the CARs for the whole test period $(-15$, $+10)$, the pre-event period $(-15,-1)$, and the on-event period $(-1,+1)$ are positively and statistically significant at the 0.01 level. However, the CAR for the post-event period $(+2,+10)$ is negative and not statistically significant. Similar to the previous results, these findings are consistent with a market that is efficient in the semi-strong form in which share prices adjust rapidly to new information.

It is noted also that the positive, average market responses regarding private placement announcements are consistent with those results obtained from U.S. studies done by Hertzel and Rees (1998), and Goh, et al. (1999); in the U.K. by Slovin, Sushka, and Lai (2000); in Sweden by Cronqvist and Nilsson (2003); in Japan by Kang and Stulz (1994); and in Hong Kong by Wu and Wang (2002).

The significantly positive AARs prior to the announcement date and the significantly positive CARs during the pre-announcement period are consistent with the adverse selection model, as proposed by Myers and Majluf (1984), in which a firm will issue equity if it believes that its prevailing share price exceeds its intrinsic value. Also, information leakage that a firm will privately place equity can explain the nature of positive AARs prior to the announcement day.

The positive share price reactions resulting from the announcement of privately placed equity in this study are also consistent with the previous evidence. Although many hypotheses (such as the tax, agency, free cash flow, and wealth transfer hypotheses, as well as the asymmetric information model) generally predict that the market will react negatively to equity issue announcements, evidence shows that the issuing method is likely to influence share price responses to new security issues. The argument for positive reactions to placement is that private investors are likely to enhance the monitoring system, as well as improving the expertise of an issuing firm, which in turn, mitigates the agency costs. However, public offerings do not offer monitoring mechanisms, nor do they increase the level of cash in hands of the manager, which results in increased agency costs. Thus, market participants react positively for they view a private placement as favourable news. 
Table 5: Daily Average Abnormal Returns and Cumulative Abnormal Returns Surrounding Private Placement Announcements

\begin{tabular}{|c|c|c|c|c|c|}
\hline & $\operatorname{AAR}(\%)$ & $\operatorname{CAR}(\%)$ & Std Dev. & SEE & $t$-statistics \\
\hline \multicolumn{6}{|c|}{ Panel A: AAR and CAR } \\
\hline-15 & 0.6488 & 0.6488 & 0.0552 & 0.0040 & 1.6158 \\
\hline-14 & 0.6646 & 1.3134 & 0.0586 & 0.0043 & 1.5595 \\
\hline-13 & 0.3426 & 1.6560 & 0.0598 & 0.0044 & 0.7873 \\
\hline-12 & 1.0077 & 2.6637 & 0.0558 & 0.0041 & $2.4834 * *$ \\
\hline-11 & 0.2435 & 2.9072 & 0.0609 & 0.0044 & 0.5497 \\
\hline-10 & 0.3012 & 3.2084 & 0.0536 & 0.0039 & 0.7721 \\
\hline-9 & 0.8124 & 4.0209 & 0.0899 & 0.0065 & 1.2428 \\
\hline-8 & 1.1253 & 5.1462 & 0.0688 & 0.0050 & $2.2496^{* *}$ \\
\hline-7 & 0.9331 & 6.0793 & 0.0483 & 0.0035 & $2.6575 * * *$ \\
\hline-6 & 0.9723 & 7.0516 & 0.0570 & 0.0041 & $2.3454 * *$ \\
\hline-5 & 0.9523 & 8.0039 & 0.0634 & 0.0046 & $2.0650 * *$ \\
\hline-4 & 0.9622 & 8.9661 & 0.0614 & 0.0045 & $2.1532 * *$ \\
\hline-3 & 0.0318 & 8.9979 & 0.0496 & 0.0036 & 0.0881 \\
\hline-2 & -0.3352 & 8.6627 & 0.0655 & 0.0048 & -0.7038 \\
\hline-1 & 1.9161 & 10.5787 & 0.0628 & 0.0046 & $4.1969 * * *$ \\
\hline 0 & 1.0756 & 11.6543 & 0.0628 & 0.0046 & $2.3539 * *$ \\
\hline 1 & 1.3317 & 12.9860 & 0.0602 & 0.0044 & $3.0411 * * *$ \\
\hline 2 & 0.1988 & 13.1848 & 0.0584 & 0.0042 & 0.4680 \\
\hline 3 & 0.0275 & 13.2123 & 0.0590 & 0.0043 & 0.0641 \\
\hline 4 & 0.0578 & 13.2701 & 0.0554 & 0.0040 & 0.1434 \\
\hline 5 & 0.2724 & 13.5424 & 0.0543 & 0.0039 & 0.6896 \\
\hline 6 & -0.1011 & 13.4414 & 0.0597 & 0.0043 & -0.2328 \\
\hline 7 & 0.2315 & 13.6728 & 0.0464 & 0.0034 & 0.6851 \\
\hline 8 & -0.6020 & 13.0708 & 0.0530 & 0.0039 & -1.5620 \\
\hline 9 & -0.5012 & 12.5695 & 0.0530 & 0.0039 & - 1.2998 \\
\hline 10 & -0.4222 & 12.1474 & 0.0594 & 0.0043 & -0.9776 \\
\hline \multicolumn{6}{|c|}{ Panel B: Cumulative windows } \\
\hline$-15,+10$ & & 12.1474 & 0.6240 & 3.1817 & $3.8179 * * *$ \\
\hline$-15,-1$ & & 10.5787 & 0.5375 & 2.0817 & $5.0817 * * *$ \\
\hline$-1,+1$ & & 4.3233 & 0.4308 & 0.7462 & $5.7940 * * *$ \\
\hline$+2,+10$ & & -0.8386 & 0.3345 & 1.0036 & -0.8356 \\
\hline
\end{tabular}

*** Indicates statistical significance at the 0.01 level.

** Indicates statistical significance at the 0.05 level.

* Indicates statistical significance at the 0.10 level.

$$
\text { a } A A R_{t}=\frac{1}{N} \sum_{i=1}^{N} A R_{i, t} \quad \text { b } C A R_{(j, k)}=\sum_{t=j}^{k} A A R_{t}
$$


Table 6: Daily Average Abnormal Returns and Cumulative Abnormal Returns Surrounding Right Issues Announcements

\begin{tabular}{|c|c|c|c|c|c|}
\hline & $\operatorname{AAR}(\%)$ & CAR (\%) & Std Dev. & SEE & t-statistics \\
\hline \multicolumn{6}{|c|}{ Panel A: AAR and CAR } \\
\hline-15 & -0.3610 & -0.3610 & 0.0448 & 0.0037 & -0.9827 \\
\hline-14 & 0.2859 & -0.0751 & 0.0421 & 0.0034 & 0.8398 \\
\hline-13 & 0.0366 & -0.0385 & 0.0451 & 0.0036 & 0.1009 \\
\hline-12 & -0.0271 & -0.0656 & 0.0501 & 0.0041 & -0.0667 \\
\hline-11 & -0.3930 & -0.4586 & 0.0448 & 0.0036 & -1.0891 \\
\hline-10 & -0.5038 & -0.9624 & 0.0441 & 0.0036 & -1.4125 \\
\hline-9 & -0.5275 & -1.4898 & 0.0411 & 0.0033 & -1.5806 \\
\hline-8 & -0.0713 & -1.5611 & 0.0388 & 0.0032 & -0.2243 \\
\hline-7 & -0.1765 & -1.7376 & 0.0427 & 0.0035 & -0.5040 \\
\hline-6 & -0.6471 & -2.3847 & 0.0462 & 0.0038 & $-1.6984 *$ \\
\hline-5 & 0.2395 & -2.1452 & 0.0442 & 0.0036 & 0.6742 \\
\hline-4 & -0.5592 & -2.7044 & 0.0501 & 0.0041 & -1.3795 \\
\hline-3 & -0.6115 & -3.3159 & 0.0501 & 0.0041 & -1.5059 \\
\hline-2 & -0.0662 & -3.3821 & 0.0408 & 0.0033 & -0.1988 \\
\hline-1 & -0.3283 & -3.7105 & 0.0473 & 0.0038 & -0.8562 \\
\hline 0 & -1.2652 & -4.9757 & 0.0399 & 0.0033 & $-3.8230 * * *$ \\
\hline 1 & -1.4059 & -6.3816 & 0.0473 & 0.0039 & $-3.6196 * * *$ \\
\hline 2 & -0.2705 & -6.6521 & 0.0503 & 0.0041 & -0.6565 \\
\hline 3 & 0.3043 & -6.3478 & 0.0547 & 0.0044 & 0.6861 \\
\hline 4 & 0.1469 & -6.2009 & 0.0424 & 0.0034 & 0.4283 \\
\hline 5 & -0.0243 & -6.2253 & 0.0419 & 0.0035 & -0.0702 \\
\hline 6 & 0.3909 & -5.8343 & 0.0571 & 0.0047 & 0.8390 \\
\hline 7 & -0.3344 & -6.1688 & 0.0561 & 0.0046 & -0.7306 \\
\hline 8 & -0.6739 & -6.8427 & 0.0420 & 0.0034 & $-1.9670 * *$ \\
\hline 9 & -0.3934 & -7.2361 & 0.0479 & 0.0039 & -1.0196 \\
\hline 10 & -0.0838 & - 7.3199 & 0.0413 & 0.0033 & -0.2503 \\
\hline \multicolumn{6}{|c|}{ Panel B: Cumulative windows } \\
\hline$-15,+10$ & & -7.3199 & 0.4380 & 2.2336 & $-3.2772 * * *$ \\
\hline$-15,-1$ & & -3.7105 & 0.3040 & 1.1775 & $-3.1513 * * *$ \\
\hline$-1,+1$ & & -2.9995 & 0.5858 & 1.0146 & $-2.9564 * * *$ \\
\hline$+2,+10$ & & -0.9383 & 0.3483 & 1.0450 & -0.8979 \\
\hline
\end{tabular}

*** Indicates statistical significance at the 0.01 level.

** Indicates statistical significance at the 0.05 level.

* Indicates statistical significance at the 0.10 level.

$$
\text { a } A A R_{t}=\frac{1}{N} \sum_{i=1}^{N} A R_{i, t} \quad \text { b } \quad C A R_{(j, k)}=\sum_{t=j}^{k} A A R_{t}
$$




\subsection{Share Price Responses to Rights Issue Announcements}

The daily AARs and CARs for the sample of rights issues are presented in Table 6. The AARs for the event date (day 0) and the day after the event date (day -1) are negative and statistically significant at the 0.01 level. In addition, the CARs for the whole test period $(-15,+10)$, the pre-event period $(-15,-1)$, and the on-event period $(-1,+1)$ are negatively and statistically significant at the 0.01 level. As is expected, the CAR for the post-event period $(+2,+10)$ is also negative, yet, not statistically significant.

The average, negative abnormal returns attributable to rights issue announcements are consistent with previous Australian studies conducted by the likes of Dehnert (1993). Dehnert (1993) had employed both mean adjusted return and risk-adjusted return (market model) methods in her study. She had also reported a two day CAR of -1 percent for the former method and -1.2 percent for the latter. These results are statistically significant at the 0.01 level. The result is similar to this study in which a negative, three-day CAR of -2.99 percent exists with statistical significance at 0.01 . In contrast to these findings, by employing monthly returns, the early Australian study by Ball et al. (1977) had reported a positive event day return of 2.6 percent. However, unlike this and Dehnert's (1993) study, Ball et al. (1977) had examined rights issues with bonus elements in their study.

The market reactions to rights issues announcements in international studies are mixed. For instance, in the U.S., Miles and Perterson (2002) and Martin-Ugedo (date?), had generally reported a statistically significant and negative abnormal return. Similarly, in the U.K., Levis (1995), Slovin, et al. (2000), and Korteweg and Reneboog (2003) had observed a negative 1 percent statistically significant abnormal return. However, these results are contrary to the findings obtained in Asia (e.g. in Japan by Cooney, Kato and Schallheim (2003); in Korea by Dhatt, Kim and Mukherji (1996); and in Singapore by Tan, Chng, and Tong (2002)). The negative share price reactions resulting from equity rights issue announcements in this study are consistent with the agency hypothesis, including free cash flow and wealth transfer hypotheses, as well as the asymmetric information theory, as discussed in previous sections.

\subsection{Analysis of Debt and Equity Event Over the Same Period}

The pattern of returns from all announcements of debt and equity offerings is consistent with the previous studies. That is, positively significant price effects to straight debt and equity private placement announcements are revealed, whereas significant negative effects are evident for convertible debt and rights issues. These results are shown graphically in Figure 1. The time series plots also indicate that share prices tend to plateau without substantially changing after the announcements.

Interestingly enough, the three-day price effects of all types of issues around the announcement date are statistically significant at the 0.01 level. While the market reacts most strongly to private placement issues, the price effect of straight debt offerings is least pronounced. Hertzel and Smith (1993) had explained that when 
issuing equity privately, a firm allows institutional investors and/or a small group of private investors to evaluate its quality closely.

These investors generally possess facilities and expertise about the market. They in fact are the hardest profit-driven investors in the market and will generally invest should a firm be undervalued. Thus, their decision to take on a private offer indicates a positive signal about an issuing firm's quality, consequently enhancing the share price of a firm. The magnitude of a positive abnormal return for private placements is correlated with the extent to which the asset is undervalued. In effect, the private placement issues in this study attract the three-day CAR of 4.32 percent, followed by the 3 percent obtained from the rights issues. The three-day CARs of convertible debt and straight debt issues are -1.19 percent and 0.6 percent, respectively. A comparison of price effects to these issues is shown graphically in Figure 1. Note that the AARs on the announcement date of straight and convertible debt are positive and negative, respectively. These values are however statistically insignificant due to a weak price effect on the event day.

Figure 1: Comparison of Daily Cumulative Abnormal Returns Surrounding Straight Debt, Convertible Debt, Private Placement and Rights Issue Announcements

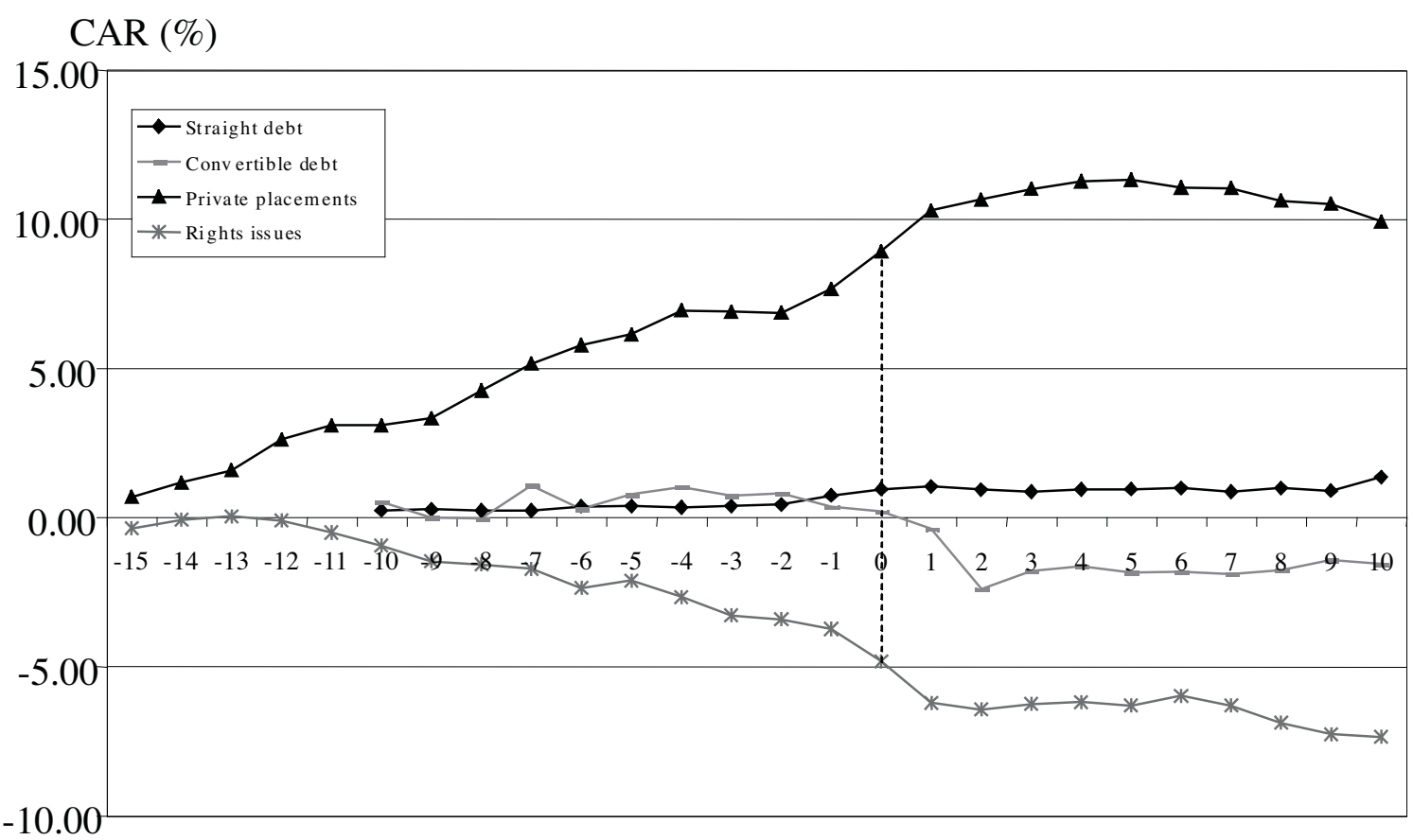

Days Relative to Announcement

\section{Conclusion}

In the past two decades, empirical studies and literature on the valuation effects of debt and equity issue announcements, as well as its methods of issue have progressed substantially. However, this kind of research is scarce in the Australian market. In Australia, debt has remained a dominant external funding source for non-financial firms, with a steady increase in debt securities outstanding from $\$ 270$ billion in 1993 
to $\$ 810$ billion in $2006 .{ }^{6}$ Australian firms nonetheless rely heavily on the equity market as a secondary source of funds. The volume of equity issues has grown substantially from $\$ 10$ million in 1993 to $\$ 61.5$ million in 2006, especially through private placement and rights issues, representing 49.8 percent of total equity raised in the Australian equity market in 2006. As there is a continuing trend towards popular funding through straight debt, convertible debt, private placement, and rights issues, as well as a rare study of price effects in the Australian market, it is appropriate to investigate the information conveyed by these securities.

This study analysed share price reactions to announcements of various types of debt and equity funding over a current 13-year period. On average, the findings indicated a positive, statistically significant share price response to the announcement of public straight debt and equity private placement issues. In contrast, a negative, statistically significant price effect to the announcement of public convertible debt and rights issues are observed. Despite the statistical significance of CARs over the three-day period surrounding the announcement of straight debt and convertible debt issues, the on-event AAR of these securities are statistically insignificant. The results however, indicate that market participants appear to use the financing information of firms at the time of announcements, reacting quickly upon the information. Over the same period, the price effect to all debt and equity issues examined in this study is consistent with the theoretical explanations from that of the agency theory to the asymmetric information model.

Author statement: Oraluck Arsiraphongphisit, School of Business, Deakin University, Australia. Email: oraluck@deakin.edu.au.

\section{References}

Arrondo, R., and Gomez-Anson, S., (2003). A Study of Spanish Firms' Security Issue Decision under Asymmetric Information and Agency Costs, Applied Financial Economics, 13, 10, 771-82.

Ball, R., Brown, P., and Finn, F., (1977). Share Capitalisation, Changes, Information and Australian Equity Markets, Australian Journal of Management, 2, 2, 105-25.

Bartholody, J., and Riding, A., (1994). Thin Trading and the Estimation of Betas: The Efficacy of Alternative Techniques, The Journal of Financial Research, $17,2,241-54$.

Berle, A. A., and Means, G. C., (1932). The modern corporation and private property, MacMillan, NY.

Brennan, M.J., and Kraus, A., (1987). Efficient Financing under Asymmetric Information", Journal of Finance, 42 (December), 5, 1225-43.

Brounen, D., and Eichholtz, M.A., (2001). Capital Structure Theory: Evidence from European Property Companeis' Capital Offerings, Real Estate Economics, $29,4,615-32$.

6 Source: Australian Stock Exchange. 
Brown, S. J., and Warner, J. B., (1980). Measuring Security Price Performance", Journal of Financial Economics, 8, 205-58.

Brown, S. J., and Warner, J. B., (1985). Using Daily Stock Returns: The Case of Event Studies, Journal of Financial Economics, 14, 3, 3-31.

Burlacu, R., (2000). New Evidence on the Pecking Order Hypothesis: The Case of French Convertible Bonds, Journal of Multinational Financial Management, 10, 3-4, 439-59.

Coase, R., (1937). The Nature of the Firm", Economica, 4, 386-405.

Cooney, J.W. Jr., Kato, H.K., and Schallheim, J.S., (2003). Underwriter Certification and Japanese Seasoned Equity Issues", Review of Financial Studies, 16, 3, 949-82.

Corrado, C. J., (1989). ANonparametric Test for Abnormal Security-Price Performance in Event Studies, Journal of Financial Economics, 23, 2, 385-95.

Corrado, C. J., and Zivney, T. L., (1992). The Specification and Power of the Sign Test in Event Study Hypothesis Tests Using Daily Stock Returns, Journal of Financial and Quantitative Analysis, 27, 3, 465-78.

Cronqvist, H., and Nilsson, M., (2003). Agency Costs of Controlling Minority Shareholders, Financial and Quantitative Analysis, 38, 4, 695-719.

Davidson III, W.N., Glascock, J.L., and Schwartz, T.V., (1995). Signalling with Convertible Debt, Journal of Financial and Quantitative Analysis 30 (September), 3, 425-40.

de Jong, A., and Veld, C., (2001). An Empirical Analysis of Incremental Capital Structure Decisions under Managerial Entrenchment, Journal of Banking and Finance, 25 (October), 10, 1857-95.

DeAngelo, H., and Masulis, R.W., (1980). Optimal Capital Structure under Corporate and Personal Taxation, Journal of financial Economics, 8, 3-27.

Dehnert, J., (1993). A Study of Rights Issues of Equity: A Theoretical and Empirical Analysis, $\mathrm{PhD}$ thesis, The Australian Graduate School of Management, University of New South Wales, Sydney, New South Wales.

Dhatt, M. S., Kim, Y. H., and Mukherji, S., (1996). Seasoned equity issues: The Korean experience", Pacific-Basin Finance Journal, 4, 31-43.

Dierkens, N., (1991). Information Asymmetry and Equity Issues, Journal of Financial and Quantitative Analysis, 26 (June), 2, 181-99.

Fama, E. F., and Miller, M. H., (1972). The theory of Finance, Dryden Press, Hinsdale, Ill.

Galai, D., and Masulis, R. W., (1976). The Option Pricing Model and the Risk Factor of Stock, Journal of Financial Economics 3, 1/2, 53-81.

Goh, J., Gombola, M. J., Lee, H. W. L., and Liu, F.Y., (1999). Private placement of common equity and earnings expectation", The Financial Review, 34, 3, 1-19.

Green, R.C., (1984). Investment Incentives, Debt, and Warrants, Journal of Financial Economics 13, 1, 115-36.

Harris, M., and Raviv, A., (1991). The Theory of Capital Structure, Journal of Finance 46, 1, 394-355.

Hertzel, M., and Rees, L., (1998). Earnings and Risk Changes around Private Placements of Equity, Auditing and Finance 13, 1, 21-35. 
Hertzel, M. G., and Smith, R. L., (1993). Market Discounts and Shareholder Gains for Placing Equity Privately", Journal of Finance 48, 2, 459-85.

Howe, J.S., and Shilling, J.D., (1988). Capital Structure Theory and Reit Security Offerings", The Journal of Finance 43 (September), 4, 983-93.

Howton, S.D., Howton, S.W., and Perfect, S.B., (1998). The Market Reaction to Straight Debt Issues: The Effects of Free Cash Flow, Journal of Financial Research, 21, 2, 219-28.

Jensen, M. C., (1986). Agency Costs of Free Cash Flow, Corporate Finance, and Takeovers, American Economic Review 76, 2, 323-29.

Jensen, M. C., and Meckling, W. H., (1976). Theory of the Firm: Managerial Behavior, Agency Costs and Ownership Structure, Journal of Financial Economics 3, 4, 305-60.

Johnson, S.A., (1995). Dividend Payout and the Valuation Effects of Bond Announcements", Journal of Financial and Quantitative Analysis 30 (September), 3, 407-23.

Kabir, R., and Roosenboom, P., (2003). Can the stock market anticipate future operating performance? Evidence from equity rights issues, Journal of Corporate Finance 9, 93-113.

Kang, J.K., and Stulz, R.M., (1996). How Different Is Japanese Corporate Finance? An Investigation of the Information Content of New Security Issues, Review of Financial Studies 9, 1, 109-39.

Korajczyk, R.A., Lucas, D., and MacDonald, R.L., (1991). The Effect of Information Releases on the Prices and Timing of Equity Issues, Review of Financial Studies 14, 685-708.

Korteweg, A. G., and Renneboog, L., (2003). The Choice Between Rights-Preserving Issue Methods. Regulatory and Financial Aspects of Issuing Seasoned Equity in the UK, Working Paper Series, Graduate School of Business and Tilburg University - Department of Finance, University of Chicago, Chicago.

Lee, H. W., and Kocher, C., (2001). Firm Characteristics and Seasoned Equity Issuance Method: Private Placement versus Public Offering, Journal of Applied Business Research, 17, 3, 23-36.

Leland, H. E., and Pyle, D. H., (1977). Informational Asymmetries, Financial Structure, and Financial Intermediation, Journal of Finance, 32, 2, 371-87.

Lewis, C.M., Rogalski, R.J., and Seward, J.K., (1997). The Information Content of Value Line Convertible Bond Rankings, Journal of Portfolio Management 24 (Fall), 1, 42-52.

(1999). Is Convertible Debt a Substitute for Straight Debt or for Common Equity? Financial Management 28 (Autumn), 3, 5-27.

(2003). Industry Conditions, Growth Opportunities and Market Reactions to Convertible Debt Financing Decisions, Journal of Banking and Finance 27 (January), 1, 153-81.

Martin-Ugedo, J.F., (2003). Equity Rights Issues in Spain: Floation Costs and Wealth Effects, Journal of Business Finance and Accounting 30, 9/10, 1277-305.

Masulis, R., (1988). The Debt/Equity Choice, Ballinger Publishing Company, U.S.A.

Masulis, R., and Korwar, A. N., (1986). Seasoned Equity Offerings: An Empirical Investigation, Journal of Financial Economics 15, 91-118. 
McWilliams, A., and Siegel, D., (1997). Event studies in management research: Theoretical and empirical issues, Academy of Management Journal 40, 3, 623-57.

Mikkelson, W. H., and Partch, M. M., (1986). Valuation Effects of Security Offerings and the Issuance Process, Journal of Financial Economics 15, 31-60.

Miles, J.A., and Peterson, M.A., (2002). An Analysis of Nonunderwritten Rights Offers: The Case of Closed-End Funds, the Journal of Financial Research, The Journal of Financial Research 25, 2, 187-206.

Miller, M. H., (1977). Debt and Taxes, Journal of Finance 32, 2, 261-75.

Miller, M.H., and Rock, K., (1985). Dividend Policy under Asymmetric Information", Journal of Finance 40, 4, 1031-51.

Modigliani, F., and Miller, M. H., (1958). The Cost of Capital, Corporation Finance and the Theory of Investment, The American Economic Review 48, 3, 261-97.

Modigliani, F., and Miller, M. H., (1963). Corporate income taxes and the cost of capital: a correction, The American Economic Review 53, 433-43.

Myers, S. C., and Majluf, N. S., (1984). Corporate Financing and Investment Decisions When Firms Have Information That Investors Do Not Have, Journal of Financial Economics, 18, 187-221.

Ross, S., (1977). The Determination of Financial Structure: The Incentive Signaling Approach, Bell Journal of Economics 8, 1, 23-40.

Slovin, M. B., Sushka, M. E., and Lai, K. W. L., (2000). Alternative Flotation Methods, Adverse Selection, and Ownership Structure: Evidence from Seasoned Equity Issuance in the U.K, Journal of Financial Economics 57, 2, 157-90.

Smith, A., (1776). An inquiry into the nature and causes of the wealth of nations, Dublin, U.S.

Smith, C. W. J., and Warner, J. B., (1979). On Financial Contracting: An Analysis of Bond Covenants, Journal of Financial Economics 7, 2, 117-61.

Stein, J.C., (1992). Convertible Bonds as Backdoor Equity Financing, Journal of Financial Economics 32 (August), 32, 1.

Strong, N., (1992). Modelling abnormal returns: A review article, Journal of Business Finance and Accounting 19, 4, 533-53.

Stulz, R., (1990). Managerial Discretion and Optimal Financing Policies, Journal of Financial Economics 26, 3-27.

Suchard, J.A., (1997). Valuation Effects of Rights Issues of Convertible Debt, Working Paper, School of Banking and Finance, University of New South Wales.

Szewczyk, S. H., and Varma, R., (1991). Raising Capital with Private Placements of Debt", Journal of Financial Research,14, 1, 1-13.

Tan, R. S. K., Chng, P. L., and Tong, Y. H., (2002). Private placements and rights issues in Singapore, Pacific-Basin Finance Journal 10, 29-54.

Wruck, K. H., (1989). Equity Ownership Concentration and Firm Value: Evidence from Private Equity Financings, Journal of Financial Economics 23, 1, 328.

Wu, X., and Wang, Z., (2002) Vol. 2003 Social Science Research Network Electronic Paper Collection. 